Marquette University

e-Publications@Marquette

Biomedical Engineering Faculty Research and

Publications

Biomedical Engineering, Department of

$7-1-2018$

\title{
Will the Real Designer Please Stand Up? [Senior Design]
}

Jay R. Goldberg

Marquette University, jay.goldberg@marquette.edu

Accepted version. IEEE Pulse, Vol. 9, No. 4 (July/August 2018): 30-31. DOI. (C) 2018 Institute of Electrical and Electronic Engineers (IEEE). Used with permission. 


\title{
e-Publications@Marquette
}

\section{Biomedical Engineering Faculty Research and Publications/College of Engineering}

This paper is NOT THE PUBLISHED VERSION; but the author's final, peer-reviewed manuscript. The published version may be accessed by following the link in the citation below.

IEEE Pulse, Vol. 9, No. 4 (July/August 2018): 30-31. DOI. This article is (C) Institute of Electrical and Electronic Engineers (IEEE) and permission has been granted for this version to appear in ePublications@Marquette. Institute of Electrical and Electronic Engineers (IEEE) does not grant permission for this article to be further copied/distributed or hosted elsewhere without the express permission from Institute of Electrical and Electronic Engineers (IEEE).

\section{Will the Real Designer Please Stand Up? [Senior Design]}

\author{
Jay Goldberg
}

Healthcare Technologies Management Program, Marquette University, Milwaukee, Wisconsin

\begin{abstract}
:
In the 1950s and 1960s, there was a popular television show called To Tell the Truth, on which three contestants claimed to be a person with an unusual occupation or distinction. Two of them were impostors, and the other was telling the truth. Four panelists asked the contestants questions to determine who was being truthful. After each panelist chose the contestant he or she thought was telling the truth, the host would ask "Will the real please stand up?" To create drama, each contestant would rise at different times and then sit, leaving the contestant with the unusual occupation or distinction standing.

This question could be asked of designers. For the last 13 years, I have been working with biomedical engineering students from Marquette University (MU) and industrial design students from the Milwaukee Institute of Art and Design (MIAD) who collaborate on capstone design projects. Over the years, I have noticed a minor turf battle for rights to the title of "designer." For example, claims were made that smartphones were designed by industrial designers. This may be true of specific aspects of smartphone design involving aesthetics, ergonomics, and general ease of use. But electrical, mechanical, computer, and software engineers designed the
\end{abstract}


internal electromechanical components and software that allow the phone and its various apps to function. Thus, I assume that a team of engineers and industrial designers (and possibly others) designed smartphones.

\section{Engineering and Industrial Design}

Differences between industrial designers and engineers have been described previously [1]-[2][3].

Engineers and industrial designers are problem solvers who use their design skills to develop new products that meet their customers' needs. Their approaches to problem solving are different, and they emphasize different aspects of design. Engineers focus on the technical aspects of design such as functionality, performance requirements, analytical modeling, and design validation. They tend to be more analytical and more concerned with product performance and the design of the internal components that make the product work. For example, engineers developing implantable medical devices are concerned with issues such as corrosion, wear, degradation, strength, and fatigue life. They perform calculations, use a variety of analytical tools (such as finite element analysis), and conduct bench tests to ensure that products are made from materials with the appropriate design characteristics (strength, biocompatibility, biodurability, etc.) and will safely perform as required. Industrial designers focus on aesthetics, ergonomics, usability, safety, and the user's experience. They tend to be more visual and more concerned with the interaction between users and products. For example, industrial designers are concerned with the psychological impact of a product's design on the user or potential customer, usability (ease of use, low potential for error), safety (no sharp edges or other potential hazards), quality of the overall product experience, and perceived value of the product. Engineers and industrial designers share a heavy emphasis on the customer, manufacturing methods, costs, and prototyping, and make extensive use of Computer Aided Design (CAD) and 3D modeling.

Engineers and industrial designers bring different perspectives, strengths, and skills to a project team.

Another difference relates to how each discipline views the design process. Engineers tend to view the process as linear and somewhat disciplined. Industrial designers consider the process to be nonlinear and chaotic. Both groups understand that the process involves iterations that loop back to previous stages. For example, engineers understand that to comply with design control requirements per ISO 9001 and ISO 13485, some stages need to be completed in a specific order, requiring a more structured design process [1].

\section{Engineers and Designers as Problem Solvers}

Members of each group claim that they are the true designers, but, in my opinion, both groups can claim this title. Engineers and industrial designers bring different perspectives, strengths, and skills to a project team while emphasizing some overlapping areas of expertise. Together, the two groups provide diverse approaches to problem solving and design.

My experience working with industrial design faculty and students taught me to think differently about the field of design. First, I prefer to think of both groups not as designers, but as problem solvers using different tools and approaches to problem solving. Second, I feel that engineering students would benefit from learning about topics that have typically been a key component of industrial design curricula but are not required as part of most undergraduate engineering curricula. These design topics include

- ergonomics and human factors

- aesthetics

- usability

- safety

- the user experience and impact of design on the customer. 
Exposure to these topics would expand students' understanding of design, strengthen their design skills, and better prepare them for careers in new product development and product design. These topics would easily be understood by engineering students and are not so complex that prerequisite courses would be required. Several of them could be introduced during the freshman or sophomore year. Some schools may already include a selection of these topics, but, for those that do not, adding them to the design curriculum would be beneficial.

\section{Incorporating Industrial Design into Engineering Curricula}

One way engineering students can learn about industrial design is through formal coursework. This can include an entire course on one topic, multiple classes (modules), or a single class period on one topic as part of a course. Videos can be viewed outside of class if class time is not available. If your institution has industrial design faculty, then they or local industrial designers could serve as guest speakers in design courses. At MU, engineering faculty and industry experts give 50-min presentations on ergonomics, human factors in design, and universal design. MIAD industrial design faculty members give presentations on the following industrial design topics:

- industrial design/aesthetics - discussion of color, form, proportions, and the use of design to create a recognizable family of products (corporate branding)

- converting specifications into concepts-identifying current solutions, making design boards and use maps, brainstorming, and modeling

- communicating your ideas - use of sketching, tracing, rendering software, and other tools to communicate a design idea

- prototype/mock-up workshop-hands-on workshop on the use of foam core, clay, urethane foam, bristle board, and other materials to create simple, quick prototypes and mock-ups to communicate design concepts.

Knowledge of industrial design topics would enhance our students' design skills and make them better designers.

Another way engineering students can learn about industrial design is to be provided with opportunities to work and interact with industrial designers either as part of a co-op or internship experience or a collaborative project with industrial design students. The collaborative student project approach has been tried at a few schools with positive results [1].

In summary, industrial designers have much in common with engineers. Both are problem solvers with a strong emphasis on the customer. Each brings a unique perspective and complementary set of skills to a design project. Knowledge of industrial design topics would enhance our students' design skills and make them better designers, and there are several ways to include these topics within the design curriculum. Providing opportunities for engineering students to work with industrial design students on projects will help prepare them for work in the medical device industry, where they may be working with industrial designers on a project team. They are both owners of the title "designer," and, by working together, they can create a more diverse set of potential design solutions that meet customer needs.

\section{References}

1. J. Goldberg, P. Malassigne, "Lessons learned from a 10-year collaboration between biomedical engineering and industrial design students in capstone design projects", Int. J. Eng. Educ., vol. 33, no. 5, pp. 15131520, 2017. 
2. W. A. Hyman, M. B. Privitera, "Looking good matters for devices too", Med. Device Diagn. Ind., vol. 27, no. 5, pp. 54-63, 2005.

3. M. Prince, Industrial design meets engineering, June 2009, [online] Available: http://www.beyonddesignchicago.com/industrial-design-meets-engineering/. 